\title{
The Oil Market Reactions to OPEC's Announcements
}

\author{
Yue Liu ${ }^{1}$, Hao Dong ${ }^{2, *(D)}$ and Pierre Failler ${ }^{3}(\mathbb{D}$ \\ 1 Hunan Institute of Technology, School of Economics and Management, Hengyang 421001, China \\ 2 School of Economics and Statistics, Guangzhou University, Guangzhou 510006, China \\ 3 Economics and Finance Group, Portsmouth Business School, University of Portsmouth, \\ Portsmouth PO1 3DE, UK \\ * Correspondence: donghao@e.gzhu.edu.cn; Tel.: +86-1831-602-8505
}

Received: 21 July 2019; Accepted: 21 August 2019; Published: 22 August 2019

check for updates

\begin{abstract}
Because of the crucial implications of the market power of OPEC, the aim of this paper was to investigate the oil asymmetric market reactions, such as the price and risk reactions, to OPEC's announcements. Specifically, this paper first explored the oil price reactions to OPEC's announcements and their heterogeneity to depict the directional role of OPEC based on event study methodology. Furthermore, this paper analyzed the oil risk reactions in the framework of a linear model. Our findings reveal several key results. The oil price reactions to OPEC production decisions behave quite heterogeneously in three kinds of decisions. Specifically, the reaction to announcements of a production increase shows an invert " $U$ " shape, whereas there is a linear effect of cut announcements. Otherwise, when a maintain decision is announced, the oil prices have no obvious change over the sample period. Additionally, the oil risk reactions to OPEC's announcements are heavily related to the interaction item between OPEC decisions and its production over full sample periods. Furthermore, OPEC's role in promoting stability in crude oil markets by changing its production shows a heterogeneous condition after global financial crisis.
\end{abstract}

Keywords: market reactions; OPEC; oil price reactions; oil risk reactions; production decision

\section{Introduction}

The geopolitical instability of the world supply sheds light on the dominant role of the Organization of the Petroleum Exporting Countries (OPEC) in the crude oil market [1,2]. On the one hand, the oil price reactions could be regarded as direct market reactions. Indeed, OPEC, as a cartel, influences the oil price through coordinating its members' production quotas. However, this impact is a conflicting issue among different stakeholders [3]. For one thing, the correlation between OPEC and oil price varies over a time horizon, because of the changing market share of non-OPEC oil production [4]. For another, the role of OPEC changes over time due to the market fundamentals. On the other hand, the risk reactions indirectly depict market responses to OPEC's announcements. As stated by Balcilar and Ozdemir [5], the higher oil price volatility is, the greater uncertainty and risk are for market participants. Moreover, the primary aim of OPEC is to assure the balance between producers and investors, in turn promoting market stability. In this vein, this paper explored the question of how oil price and risk react to OPEC's announcements. The logical relations among these three sides are shown in Figure 1.

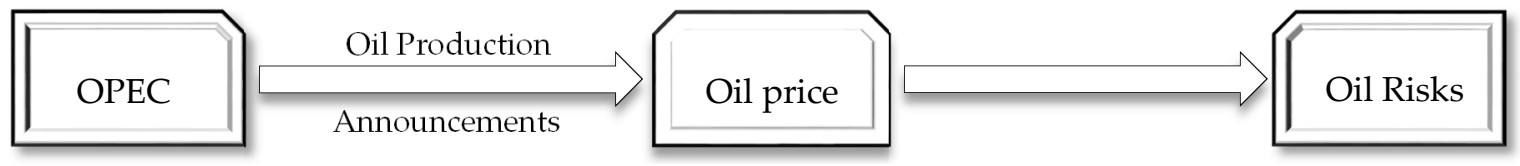

Figure 1. The logical relations among oil price reactions and oil risk reactions to OPEC's announcement. 
The oil price reactions could depict the market power of OPEC. As we all know, future oil production for OPEC members is announced by OPEC conferences, based on the outlook of the balance between oil supply and demand. Obviously, OPEC's exercise of market power restrains its production level to maintain higher oil prices and decrease its markets share of oil production related to competitors [1]. Because of the benchmark role on pricing oil and other related oil derivatives, Figure 2 presents the Brent spot price reactions to OPEC conferences from 2002 to 2018. Among them, OPEC announcements, especially those agreeing to cutting or increasing production, have diverse impacts on oil prices. Moreover, OPEC is better off making a maintain decision, for the most part, when taking the change in oil demand into account. This is due to the fact that OPEC exercises its market power to control the oil price [6]. In this sense, instead of precisely estimating OPEC's behavior, this paper investigated the oil price reactions to OPEC's announcements.

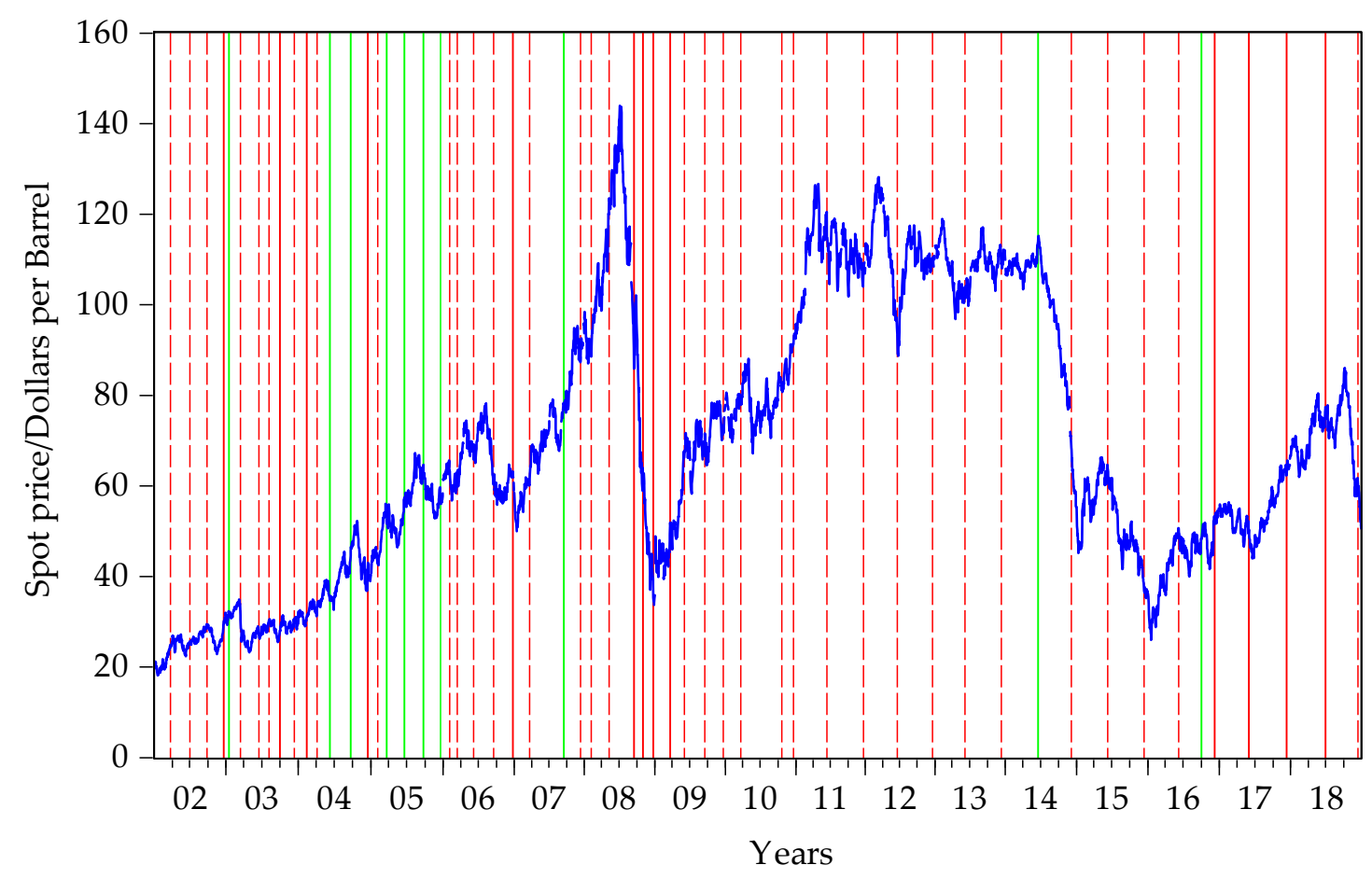

Figure 2. Brent spot prices and OPEC's announcements. The solid, red line represents the "cut decision", the green line shows the "increase decision", and the dotted, red line depicts the "maintain decision".

Since the seminal work by Draper [7], abundant papers have explored how announcements or major events are impounded into financial asset prices [8-12]. However, little literature deals with the price reactions to the different types of OPEC's announcements based on the event study methodology. Indeed, Draper [7] first attempted to explore the oil future price reactions between fall 1978 and 1980 and found that OPEC's announcements were impacted by investors' expectations. Recently, Ji and Guo [13] investigated that there are inconsistent reactions to OPEC's announcements. Loutia et al. [3] analyzed the crude oil prices as well as two benchmark indices over two sub-periods, distinguishing that oil price uniformly increased and were turbulent. They found that the oil price reactions to OPEC's announcements evolve over time and among decisions, and these reactions are more significant for production cut and maintaining. In addition, OPEC's announcements are also sensitive to the benchmark index. However, studies that model oil price reaction to OPEC's announcements during pre- and post-crisis periods are scarce.

Additionally, high return risks create increased uncertainty in crude oil markets. Indeed, the oil return risks could inhibit current investment for crude oil [5]. Changes in market stability have considerable impacts on economy [14-18]. First, changes in crude oil return risks essentially impact decisions made by market participants, such as oil producers, consumers, and policy makers. Otherwise, 
changes in oil return risks also determine investors' decisions for pursuing maximum profits. In this sense, this paper further explored the oil risk reactions to OPEC's announcements. Theoretically, there are asymmetric risk reactions to OPEC's announcements over time horizons. The announcement of OPEC's decision generally exerts a simultaneous impact on oil return risks, that could be regarded as a source of participants' attention [19]. Because of the nature of OPEC's announcements, its role is perceived differently by the global crude oil market fundamentals.

Not surprisingly, an increasing number of studies have been exploring the consequences of OPEC's power to promote market stability. For example, models are often constructed to conduct theoretical and empirical analyses on OPEC announcements' role on oil prices, using production quotas, market competition, and spare capacity [20-24]. Besides, a common belief is that the market role of OPEC changes between an oil producer and a cartel, which in turn makes oil markets deviate largely from competition [25]. Another view is related to economic, market, and geopolitical conditions, indicating that OPEC's behavior is time-varying and this effect cannot be described by a single model [21]. Moreover, the linkage between oil price volatility and OPEC's announcements has been analyzed in the literature. For instance, Schmidbauer and Rösch [26] provided evidence that there is a strong effect on oil volatility as there is an asymmetric post-announcements effect on volatility. Mensi et al. [27] argued that the "cut" or "maintain" decisions play a dominant role on the oil price volatility. Furthermore, the potential ability in OPEC members to stabilize the oil price could be related to the spare capacity [28]. However, sparse attention has been paid to the analysis of oil risks.

The main contributions, which were the primary objectives of this paper, were to explore the oil asymmetric market reactions to OPEC's announcements. First, based on an event study methodology, this paper contributes to research on the oil price reactions to OPEC's announcements during distinct periods (pre- and post-financial crisis). More precisely, this objective aims to depict the direct market reactions to OPEC's announcements as mentioned above. Our second contribution is to explore the indirect market reactions to OPEC production decision, as well as investigating the heterogeneity during two distinct periods. To achieve this goal, we investigated the asymmetric risk reactions to OPEC's announcements in a framework of a linear model. Unlike existing studies focused on the influence of OPEC announcements to oil price volatility, we explored the asymmetric impacts on oil return risks. Additionally, Lin and Tamvakis [29] did not find a significant difference between oil qualities. Thus, the potential reactions to OPEC's announcements as the regressors are explicitly specified in a linear regression framework. Moreover, we divided the sample periods into two sub-periods because of the potential shock of global financial crisis in crude oil markets [30]. Importantly, this allows us to assess the heterogeneous role of OPEC in oil markets after global financial crisis.

The remainder of this paper is organized as follows. Section 2 briefly introduces the research hypothesis supported in this paper. Section 3 presents and discusses the oil price reactions to OPEC's announcements. In Section 4, we proceed to model the oil risk reactions to OPEC's announcements. Finally, the conclusions and policy implications are described in Section 5.

\section{Research Hypothesis}

The oil price reactions to OPEC's announcements are heterogeneous, during both pre- and post-crisis periods. It is well known that the oil price reactions can be foreseen by market participants. In other words, the oil price reactions to these decisions are asymmetric. Specifically, an increase decision in oil supply can drive price up. In terms of oil producers, the optimistic attitude held by OPEC members for an increase in production plays a dominant role in crude oil markets. For other investors, they cannot change the investment decision to an increase production because of their expectations. In this sense, the expectations of market participants promote them to pursue higher profits, which in turn lead to the oil price increase. Additionally, the oil price reaction to increase announcements is heterogeneous during pre- and post-crisis periods. This is not surprising due to the market fundamentals. For one thing, OPEC can be regarded as a marginal producer in order to partially control the imbalance between global oil demand and oil supply for non-OPEC producers 
through its members' quota. For another, non-OPEC oil producers can be regarded as price takers, meaning that there are few price reactions during pre-crisis periods. Thus, the oil price reactions to increase announcements vary during the post-crisis periods. Taking all these considerations together, it is obvious that the reactions of oil price to an increase announcement could be interpreted by market participants.

The picture changes a little for quota reduction. Following a cut decision, oil prices should go up. Indeed, oil prices heavily depend on the expectations of market participants. When a cut production decision is announced, it means that the production quota incudes the crude oil market's anticipation and the information on evolution of oil price. At this time, the imbalance between oil supply and demand could be expanded by quota reduction, thus driving oil price up. However, a different story may emerge. Despite the quota reduction, the oil prices could continue to decrease. This picture is more pronounced during post-crisis periods. The possible explanation for decreasing price is that the cuts in oil production perceived in the market are not far-reaching enough, or they suggest that OPEC's exercise of market power is not enough to enforce the quota reduction on its members. This apparently counterintuitive story could also indicate expectations about oil supply and demand and market participants' concern of the market power of OPEC as a cartel, as well as the actual oil production. Moreover, the upward pressure on oil prices could be impacted by world economic growth and spare capacity in oil producers.

In the case of maintain decision, the double reactions of oil price to OPEC announcements are related to market fundamentals. On the one hand, in crude oil markets, a maintain decision could be regarded as "firm indecisiveness". In this sense, it is easier to consider that members' expectation to market fundamentals should be a negative, but different interests of OPEC members could make it difficult to change the status of oil production, which in turn flow the oil supply and drive oil price further down. On the other hand, OPEC also focuses on other economic parameters. Specifically, market fundamentals, expectations of economic growth, or geopolitics could change the OPEC production quota. In other words, that the market interprets an unchanged decision in oil production means there is a sufficient level of supply. Thus, oil prices could continue to increase. Taking all these effects together, it is obvious that the oil price reaction is moderate. However, there are heterogeneous reactions of oil price during pre- and post-crisis periods. These results could be interpreted by depicting non-conventional resources, such as shale formations and natural gas production, and the increasing role of non-OPEC oil production in crude oil markets.

Accordingly, this paper proposes the following hypothesis:

Hypothesis 1. The oil price reactions to OPEC's announcements vary across production decisions during pre-and post-crisis periods. Specifically, the oil price reaction to the increase or cut in production is dramatic, whereas it is moderate when the production remains unchanged.

There are asymmetric reactions of oil risk to OPEC's announcements and these reactions heavily relate to production decision and quota level. The key reason for oil risk reactions is the uncertainty of oil supply or demand. Obviously, financial risk captures the loss but not profit in crude oil markets [31]. Indeed, oil risks could be defined as the excessive return on oil prices during distinct periods, which is a desirable characteristic in crude oil market applications to capture the market stability [32]. The different OPEC announcements could result in conflicting expectations in the oil markets and promote different investment decisions for speculation or hedging, thereby resulting in the asymmetric reactions of the oil risks [33]. From the perspective of an unchanged decision in oil production, it means that the quota level is tolerable in the oil markets. Meanwhile, the upward pressure in the oil markets caused by economic factors and uncertainty over supply and demand could be regarded as an unstable resource of oil risks. Thus, the oil risk reactions to the maintain decisions are the largest over these decisions. Additionally, the reactions of oil risks to the production increase decisions are larger than those to the cut decisions. This asymmetric picture could be related 
to the expectation of market participants. Indeed, the production hike decisions could be regarded as "good news" for market investors. Speculation is blamed. It is well known that speculative flows accentuate the oil risks. On the contrary, the production cut decisions will lead to the oil price increase and further ensure the interest of different stakeholders. However, changes in oil production could also lead to the uncertainty of oil supply or demand, which results in the uncertainty of market stability. Therefore, it can be noticed that OPEC's announcements could promote the oil risks instead of being a stabilizing force. As mentioned above, it can be noted that:

Hypothesis 2. The oil risks reactions depend on the interaction between OPEC's announcements and OPEC oil production.

Moreover, there are heterogeneous reactions of oil risks to OPEC's announcements during pre- or post-crisis periods. Obviously, the recent global financial crisis could lead to some new changes in oil markets, such as the oil pricing mechanism, oil supply and demand for several countries, and the dependence between oil markets and other financial markets [34]. Therefore, this heterogeneous story may be caused by these differences. At a more specific level, during the pre-crisis periods, the production increase decisions significantly promote the market stability, whereas the oil risk reactions to another production decision are unapparent. As shown in Figure 2, the oil price increases significantly in pre-crisis periods, and its volatility is moderate. It is also interesting to note that the oil price experienced a sharper change for production hike decisions than others. This is not a surprise but due to the determinant role of oil supply factors during pre-crisis periods [35]. Theoretically, in a relatively weak market, the production hike decisions could mean an optimistic attitude for decision makers, which will lead to reasonable expectations of market participants and promote the demand in oil markets. Furthermore, these characters are expected to decrease the oil price volatility and stabilize the crude oil markets.

As the sample moves out to post-crisis periods, the oil risk reactions to different OPEC announcements depict a different picture. Inconsistent with pre-crisis periods, there are obvious reactions of oil risks to the cut decisions, and the oil risk reactions to the production maintain decisions are heavily related to the interaction item between decision and OPEC oil supply. As we all know, the key reason for these results is the uncertainty of oil supply or demand. Additionally, another reasons of oil markets' stability are the attitudes for production change in OPEC announcements. Indeed, these different pictures during post-crisis periods are determined by the sharp increase in oil demand and the change in market share for non-OPEC countries. For another, the maintain decision is often perceived as non-decisions. In this vein, the oil price would tumble further down, leading to different expectations of market participants and promoting different capital flows in the crude oil markets [36]. Additionally, economic parameters or geopolitical events could also lead to the reactions of oil risks to OPEC's production decisions. Furthermore, the diverse interests of OPEC's members make it difficult to reach production decisions and further promote the oil risks. Therefore, this paper concludes with the following hypothesis:

Hypothesis 3. The oil risk reactions to OPEC's announcements in a sense are heterogeneous during pre- and post-crisis periods.

\section{The Oil Price Reactions to OPEC's Announcements}

\subsection{Event Study Methodology}

To exam the asymmetric price reactions to different OPEC announcements in crude oil markets, we used an event study methodology. It is easier for the event study methodology to assess the significance of global crude oil price reactions to OPEC announcements [37]. Furthermore, the expected return of oil price could be good for capturing the seasonality and rationality features [29]. In addition, because of the change in Brent crude oil demand of emerging countries and the controlling crude 
oil export of the US government in recent years, Brent has become the international oil benchmark. Although Brent has been activated in Europe, it can also be used to assess the basic price for other grades. In this way, we examined the effects of OPEC announcements on the Brent oil spot price. In this section, we used the daily price covering the period from 1 January 2002 to 31 December 2018. Data was collected from the US Energy Information Administration.

The point of using event study was to forecast the abnormal returns of oil prices during the event window of OPEC announcements. This was measured in Formula (1).

$$
A R_{t}=R_{t}-\mathrm{E}\left(R_{t}\right)
$$

where $A R_{t}$ is the abnormal return of the oil price at $t ; R_{t}$ is the log-return on crude oil price, and $\mathrm{E}\left(R_{t}\right)$ stands for the expect return, which assumes that the OPEC announcement is not taking place (following Ji and Guo [13] and Lin and Tamvakis [29], $\mathrm{E}\left(R_{t}\right)$ was equal to 0 in this paper, which indicates that there will be no change in the price over the short term without exogenous shocks).

The cumulative abnormal returns (CARs) can be regarded as the sum of the daily abnormal returns over the event window. In this paper, an event window of 11 days (five days before and five days after the event date) was set (see also Loutia et al. [3] and Ji and Guo [13]). The reasons we used this choice are as follows. Firstly, the five days before the event date could better depict the picture before the OPEC announcements. Additionally, the five days after the event date capture the information after the decisions. Furthermore, this choice can also better avoid the interactional effects from other events. Thus, the CARs can be defined as in Formula (2).

$$
C A s_{i}=\sum_{t=-5}^{5} A R_{t}, i=1,2,3 .
$$

where $i$ refers to the type of OPEC announcements.

Then, this paper calculated the average CARs for different types of OPEC announcements with Formula (3).

$$
\overline{C A R}_{t}=\frac{1}{N} \sum_{e=1}^{N} C A R s_{i_{e}, t} .
$$

where $N$ is the number of different types of OPEC announcements over the sample period, and $t$ is the date of event windows, which equals from -5 to 5 . In this vein, we obtained the average CARs of different types of OPEC announcements during the event windows.

\subsection{The Reaction of Oil Price to Announcements}

In this subsection, we present the average cumulative abnormal returns for different categories. Table 1 represents the OPEC's announcements from 1 January 2002 to 31 December 2018. There were 57 OPEC regular and extraordinary conferences which can be divided into three categories according to different decisions. Of those decisions, 13 announced production cuts, 10 announced production increases, and 34 announced production maintenance. The details in Table 1, such as the dates, the production decisions, and the price series of Brent spot prices (in USD/barrel) are available upon request. We set the OPEC announcement day as $t=0$ in Formula (2) when the actual announcement was released.

Figure 3 plots the trend in the average CARs for three types of OPEC announcements. According to existing literature, the result that the price reactions to announcements are generally not significant could not be related to the choice of commodity index [38-44]. This phenomenon could be correlated with OPEC's market power. For example, Lin and Tamvakis [29] explored the oil price reactions to OPEC's announcements from 1982 to 2008 and found diverse market reactions to OPEC's announcements under different price bands. Most generally, the oil price reactions to OPEC's announcements may be heterogeneous during distinct periods. Another argument is put forward by Loutia et al. [3]. 
He explained these heterogeneous results by an explanation that it is easier for market participants to agree to an increase decision, whereas the reactions of oil price to the production cut decision reflects the expectation of market participants. However, economic parameters, such as economic growth, geopolitical events, and spare capacity, can also be regarded as causes of oil price change.

Table 1. OPEC's announcements.

\begin{tabular}{cc}
\hline OPEC Meeting & $\begin{array}{c}\text { Number of } \\
\text { Announcements }\end{array}$ \\
\hline OPEC production cut & 13 \\
OPEC production increase & 10 \\
OPEC production maintain & 34 \\
Total OPEC meeting & 57 \\
\hline
\end{tabular}

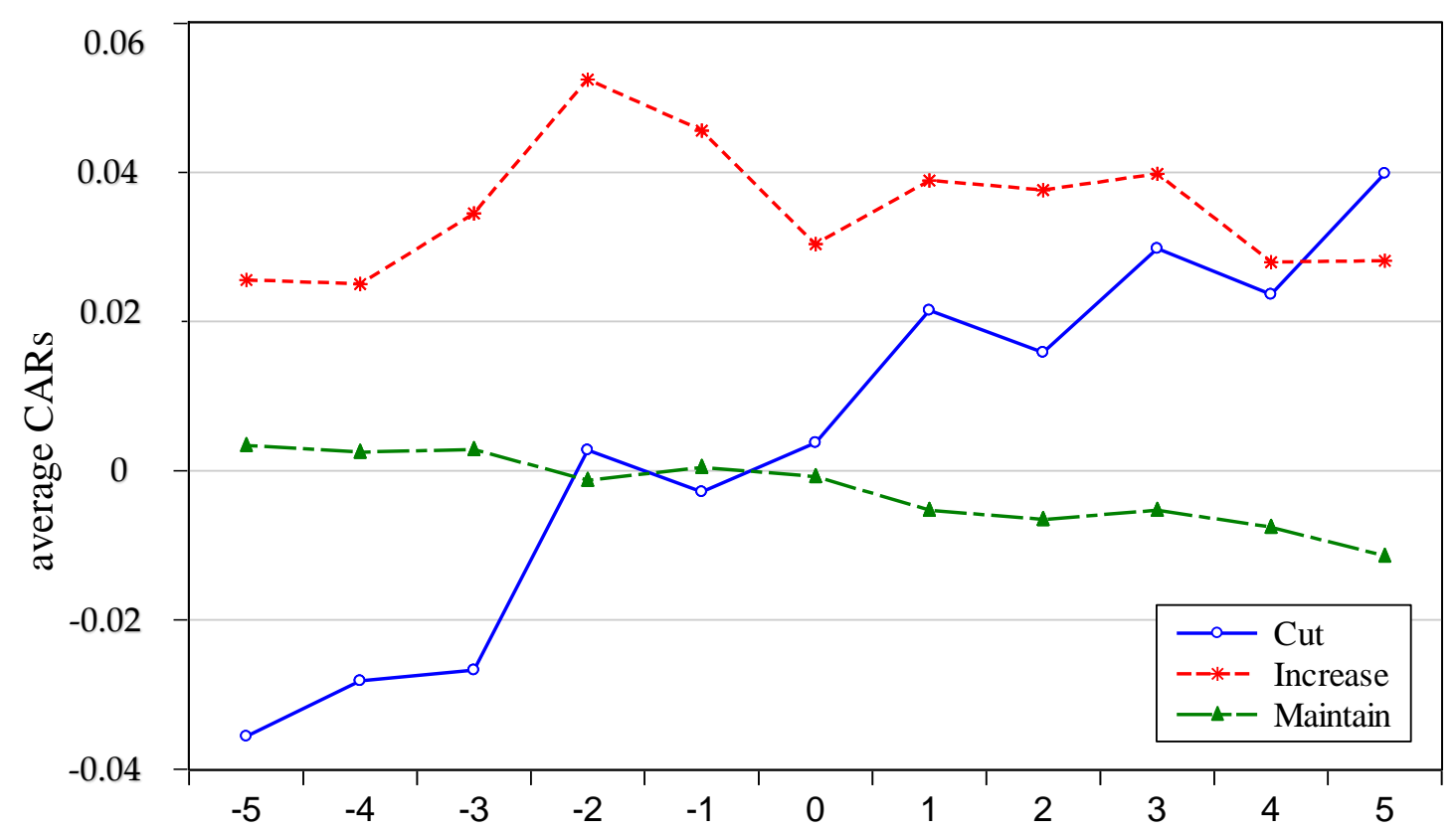

Figure 3. Average CARs of the Brent spot prices for OPEC's announcements from five days before the event to five days after the event.

As expected, the oil price reactions to OPEC announcements display obvious asymmetry. These results follow the expectation that an increase production announcement shows an invert " $U$ " effect, whereas there is a linear reaction to cut decision. In addition, it seems that if the OPEC maintains its production, there is no significant reactions of crude oil prices. This indicates the role of market fundamentals on crude oil markets. On the one hand, market participants focus on digesting the newly released announcements, and the influence of the cut announcement has a strong persistence over a short period of time. On the other hand, the maintain decision often means stability of the market, thus the market responds moderately to it. Furthermore, this paper examed the heterogeneous reaction of oil price to OPEC's announcements during pre- and post-crisis periods. Figure 4 presents the average CARs for the three types of OPEC decisions.

The picture changes a little during different sample periods. As shown in Figure 4, it is clear to note that the oil price reactions to OPEC's announcements were heterogeneous during distinct periods. In particular, an increase decision will drive prices up during pre-crisis periods. However, the increase announcement could drive oil prices to drop first, and then oil prices will go up during post-crisis periods. This is not a surprise due to the fact that OPEC often acts as a marginal producer in order to offset, whereas non-OPEC is generally considered as a price taker during pre-crisis periods $[37,38]$. 
Thus, the greater the OPEC supervision is, the greater reaction oil prices have. However, the market power of OPEC could be limited by its market share.
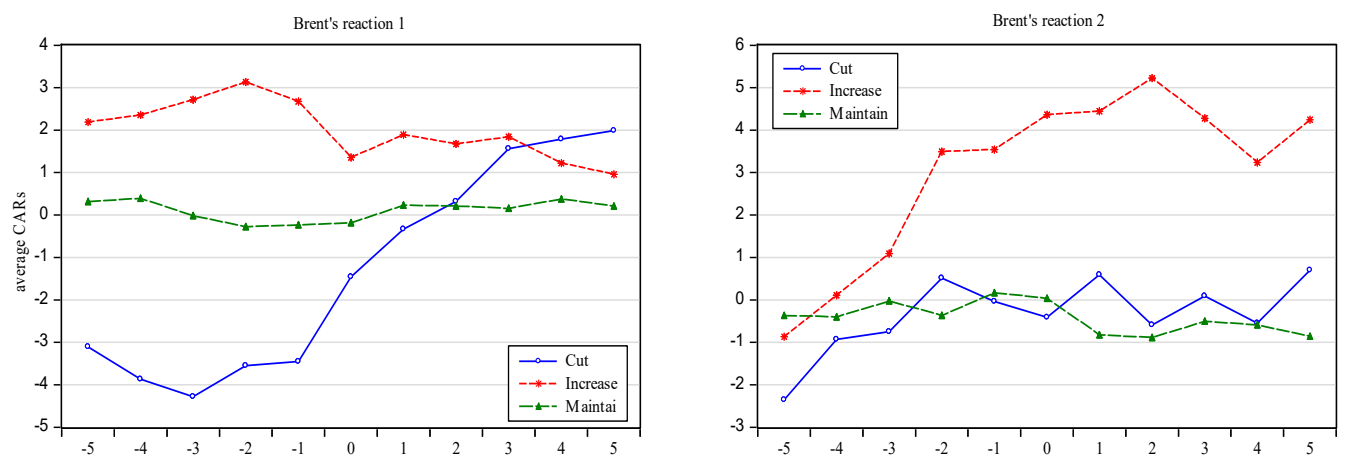

Figure 4. Average CARs of Brent spot price for OPEC's announcements during two periods. Brent's reaction 1 refers to the oil price reaction during pre-crisis periods, whereas Brent's reaction 2 represents the price reaction during post-crisis periods.

When a cut decision is announced, the reaction seems more sensitive to oil price during pre-crisis periods than in the post-crisis periods. Following a cut decision, oil prices should go up, thus the average CARs should be positive. This is indeed the case for the pre-crisis periods for Brent spot price. It is particularly interesting to note that the average CAR is always negative in pre-announcement period $(t=-5,-4, \ldots,-1)$ during pre-crisis periods. This interesting information could be depicted by putting the excess return and market power of OPEC into the reasoning. In fact, OPEC's members exercise their market power to manipulate the oil prices down through disseminating the information about production decision for extreme profits. However, during the post-crisis periods, the average CAR is negative. This obviously unreasonable result may indicate considerations about the balance between oil supply and demand and market participants' attention to the power of OPEC as a cartel, as well as the change in production [39]. Additionally, as shown in Figure 2, OPEC's cut decisions announced in 2008 sent oil prices significantly down, and before a sharpened increase in 2009 during post-crisis periods. In fact, from 2009 to 2011, economic parameters such as economic growth and oil demand were active, whereas the lower oil production and spare capacity held by oil producers put upward pressure on oil prices. Finally, it is particularly interesting to note that the oil price reaction is moderate when the production quotas remain unchanged. As mentioned above, we can confirm that Hypothesis 1 is valid.

\section{The Oil Risk Reactions to OPEC's Announcements}

\subsection{Linear Model Specification}

Having found an asymmetric reaction to OPEC's announcements of oil price during distinct periods, we further empirically identified the oil risk reactions to OPEC's announcements. Our dataset covered the period from January 2002 to December 2018. Considering the data availability for the control variable, we used monthly data to explore the oil risk reactions to OPEC announcements, retrieved from OPEC. For this purpose, the empirical model to be estimated in this paper is shown in Formula (4). Additionally, we also provide a brief description of all variables in Table 2.

$$
\text { Risk }=\mathbf{c}+\alpha \mathbf{D}+\beta \mathbf{X}_{\mathbf{i}}^{\prime}+\varepsilon
$$

where Risk refers to the oil return risks; $\mathbf{D}$ is a vector of dummy variables to measure the periods of OPEC's announcements; $\mathbf{X}$ stands for control variables, and $\varepsilon$ is the error term. 
Table 2. Description of variables.

\begin{tabular}{|c|c|c|c|}
\hline & Variables & Abbreviation & Description \\
\hline Dependent variables & Oil risks & Risk & $\begin{array}{l}\text { The oil return risks which are measured by the } \\
\text { asymmetric slope model. }\end{array}$ \\
\hline \multirow{3}{*}{ Explanatory variables } & OPEC increase & inc & $\begin{array}{l}\text { Dummy variable equal to one if the periods belong } \\
\text { to the "increase sample" and zero otherwise. }\end{array}$ \\
\hline & OPEC cut & cut & $\begin{array}{l}\text { Dummy variable equal to one if the periods belong } \\
\text { to the "cut sample" and zero otherwise. }\end{array}$ \\
\hline & OPEC maintain & mai & $\begin{array}{l}\text { Dummy variable equal to one if the periods belong } \\
\text { to "maintain sample" and zero otherwise. }\end{array}$ \\
\hline \multirow{5}{*}{ Control variables } & Oil supply & OP & OPEC oil production. \\
\hline & Oil demand & STO & OECD total commercial oil stocks. \\
\hline & World economy & WGDP & The growth rate of global economy. \\
\hline & Future returns & FR & The monthly log-returns in the NYMEX WTI \\
\hline & Product price & PRO & The gasoline price. \\
\hline
\end{tabular}

The dependent variable Risk is oil return risks. As we all know, value-at-risk (VaR) is defined as the maximum loss in oil markets. A large body of studies pays attention to some alternative methods to forecast the risks [45-49]. Commonly, these methods often assume that the oil return is invariable. In general, the speculative and intra-cluster make oil return risks more dynamic [50,51]. Therefore, we use the CAViaR, proposed by Engle and Manganelli [52], to calculate the oil return risks in this paper. Specifically, compared with other specifications, we forecast the oil return risks based on the asymmetric slope from the results of a dynamic quantile (DQ)test at the 5\% level (these results are available upon request).

The main explanatory variables are OPEC's announcements. The OPEC's announcements are coded based on the OPEC decisions on oil production. To solve this problem, we defined three dummy variables. Take increase (inc) as an example: the measurement of inc is shown as Figure 5 (other dummy variables are the same as inc). If an increase production decision is announced at time $b$, we could regard the period from $a$ to $b$ as an increase sample.

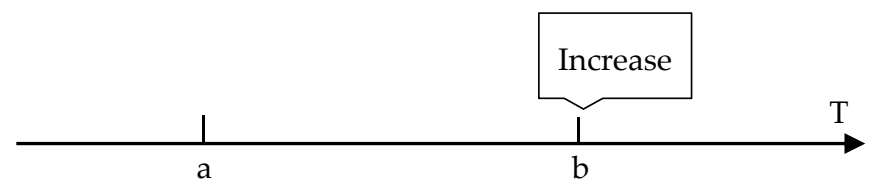

Figure 5. Example for inc: $a$ and b represent the date of the OPEC announcement.

The control variables included commonly used background variables. Referring to the OPEC monthly oil market reports (MOMRs), we considered several main strands of potential factors, including oil supply and demand, world economy, and spillover from other markets. For the perspective of oil supply and demand, we selected OPEC oil production and OECD commercial oil stocks, respectively, because of their market power. Additionally, the growth rate of the global economy could better depict the world economy. In terms of spillover from other markets, it is well known that oil futures or product markets play a dominant role on oil spot price. Thus, we selected the log-return of NYMEX WTI and the gasoline price. All data were monthly observations and collected from OPEC.

Above all, we estimated the following empirical specifications in different periods. Since in Section 3 we found that oil price volatility was low when the production remained unchanged, this paper regarded inc and cut as the regressors. This can be seen in Formulas (5) and (6).

$$
\begin{aligned}
\text { Risk }=\mathrm{c}+ & \alpha_{1} \text { inc }+\alpha_{2} \mathrm{cut}+\beta_{1} \mathrm{OP}+\beta_{2} \mathrm{STO}+\beta_{3} \mathrm{WGDP}+\beta_{4} \mathrm{FR}+\beta_{5} \mathrm{PRO}+\varepsilon . \\
\text { Risk }= & \mathrm{c}+\alpha_{1} \text { inc }+\alpha_{2} \mathrm{cut}+\beta_{11} \mathrm{OP} \times \mathrm{cut}+\beta_{12} \mathrm{OP} \times \text { mai }+\beta_{13} \mathrm{OP} \times \text { inc } \\
& +\beta_{2} \mathrm{STO}+\beta_{3} \mathrm{WGDP}+\beta_{4} \mathrm{FR}+\beta_{5} \mathrm{PRO}+\varepsilon .
\end{aligned}
$$


Our interest mainly lies in the $\alpha_{1}, \alpha_{2}, \beta_{11}, \beta_{12}$ and $\beta_{13}$ coefficients which provide information on the asymmetric effect between OPEC's announcements and oil return risks.

\subsection{The Reactions of Oil Risks to Announcements}

Table 3 shows the estimated results for the full sample. In the first column, the results without the interaction item between OPEC production and announcements are given. In columns 2-5, we augmented the interaction item between OPEC production and its announcements.

Table 3. Estimation results.

\begin{tabular}{cccccc}
\hline Model & $\mathbf{( 1 )}$ & $\mathbf{( 2 )}$ & $\mathbf{( 3 )}$ & $\mathbf{( 4 )}$ & $\mathbf{( 5 )}$ \\
\hline Variables & & & & & \\
c & $2.099^{* * *}(0.593)$ & $0.396(0.583)$ & $0.614(0.496)$ & $0.642(0.534)$ & $1.711^{* *}(0.648)$ \\
inc & $-0.014^{*}(0.008)$ & $-0.007(0.009)$ & $1.059^{* * *}(0.269)$ & $-0.187(0.008)$ & $0.197(0.605)$ \\
cut & $-0.005(0.008)$ & $0.281(0.377)$ & $1.072^{* * *}(0.269)$ & $0.004(0.175)$ & $0.605(0.372)$ \\
OP $\times$ cut & & $-0.077(0.106)$ & & & $0.286^{*}(0.128)$ \\
OP $\times$ mai & & & $0.302^{* * *}(0.076)$ & & $0.457^{* * *}(0.096)$ \\
OP $\times$ inc & & & & $0.051(0.175)$ & $0.398^{*}(0.187)$ \\
OP & $0.426^{* * *}(0.094)$ & & & \\
STO & $-0.378^{* * *}(0.098)$ & $-0.008(0.073)$ & $-0.151^{* *}(0.069)$ & $-0.038(0.067)$ & $-0.344^{* * *}(0.101)$ \\
WGDP & $-0.024^{* * *}(0.006)$ & $-0.018^{* *}(0.006)$ & $-0.021^{* * *}(0.006)$ & $-0.018^{* *}(0.006)$ & $-0.023^{* * *}(0.006)$ \\
FR & $-0.130^{* * *}(0.035)$ & $-0.159^{* * *}(0.036)$ & $-0.138^{* * *}(0.035)$ & $-0.159^{* * *}(0.036)$ & $-0.126^{* * *}(0.035)$ \\
PRO & $-0.074^{* * *}(0.014)$ & $-0.019(0.009)$ & $-0.049^{* * *}(0.010)$ & $-0.022^{*}(0.008)$ & $-0.073^{* * *}(0.014)$ \\
\hline Observations & 204 & 204 & 204 & 204 & 204 \\
adjusted- $R^{2}$ & 0.236 & 0.159 & 0.219 & 0.157 & 0.238 \\
F & $9.969^{* * *}$ & $6.506^{* * *}$ & $9.177^{* * *}$ & $6.426^{* * *}$ & $8.079 * * *$ \\
ARCH & 1.152 & $2.148^{*}$ & $1.661^{*}$ & $2.088^{*}$ & 1.231 \\
\hline
\end{tabular}

Note: standard errors are shown in parentheses. ${ }^{*}, * *$ and, ${ }^{* * *}$ indicate significance at $0.10,0.01$, and 0.001 , respectively.

Some interesting results, correlated with the OPEC announcement variables, are shown in Table 3. We noted that there were asymmetric risk reactions to different types of OPEC announcements. Actually, the individual OPEC production announcements had an effect, which heavily correlated with the OPEC oil supply. It is worth noting, refer to column 5 in Table 3, that the interaction item between OPEC maintain decisions and its production had the highest positive influence on oil return risks, while it, with cut decision, was the smallest. This is due to the fact that the market participants' attention to different types of production decisions was asymmetric. When a maintain oil production is announced, the OPEC oil production can promote the instability of the oil markets because of the participants' expectations [53-56]. Therefore, oil return risks will increase by impacting the market participants' expectations when the oil supply is opposite to the OPEC announcements. Additionally, oil return risks could be related to forecasting future supply, which is associated to the market conditions [57]. Taking all these considerations together, OPEC's announcements could be regarded as a sign in the oil market, signaling a greater market power of OPEC and, thus, resulting in uncertainty in the oil market.

Considering the increasing market share of non-OPEC producers and the global effect of the financial crisis in 2008, this paper further explored the heterogeneous effects of OPEC's announcements on oil return risks during distinct periods. The estimation of Formulas (5) and (6) are reported in Table 4.

A comparison of Table 4 reveals there are twofold heterogeneous risk reactions to OPEC's announcements during pre- and post-crisis periods: the single and interaction items. From the perspective of the single effect of OPEC's announcements, it is interesting to note that there are significant risk reactions to OPEC increase decisions during pre-crisis periods (this result refers to column 1 during the period 2002M01-2008M08), while the "cut decision" plays a positive role on oil risks (this result refers to the column 5 during the period 2008M09-2018M12). This is not a surprise but is due to the heterogeneous market conditions during pre- and post-crisis periods [58]. Indeed, the change in oil production enhances the demand in the crude oil markets and the participants' expectations, thereby promoting the stability of oil markets during pre-crisis periods. Contrary to this 
mechanism, the cut decisions in production are more sensitive during post-crisis periods than they are in first sub-periods. Obviously, the cut decision could change the fundamental balance between oil supply and demand in crude oil markets, which can influence the oil return risks level.

Table 4. Estimation results during pre- and post-crisis periods.

\begin{tabular}{|c|c|c|c|c|c|c|c|}
\hline \multirow{2}{*}{ Period } & \multicolumn{2}{|c|}{ 2002M01-2008M08 } & \multicolumn{5}{|c|}{ 2008M09-2018M12 } \\
\hline & (1) & (2) & (1) & (2) & (3) & (4) & (5) \\
\hline \multicolumn{8}{|l|}{ Variables } \\
\hline c & $-1.742(1.158)$ & $-1.788(1.335)$ & $7.190^{* * *}(1.056)$ & $4.815 * * *(1.142)$ & $5.633 * * *(0.979)$ & $6.471^{* * *}(1.084)$ & $5.059^{* * *}(1.180)$ \\
\hline inc & $-0.016 *(0.009)$ & $-0.053(0.666)$ & $-0.003(0.014)$ & $-0.004(0.014)$ & $2.547^{* * *}(0.614)$ & $-0.172(1.569)$ & $1.028(1.482)$ \\
\hline cut & $0.003(0.010)$ & $0.161(0.459)$ & $-4.08 \times 10^{-5}(0.010)$ & $2.894 * *(1.001)$ & $2.564^{* *}(0.616)$ & $0.006(0.010)$ & $4.077^{* * *}(1.023)$ \\
\hline $\mathrm{OP} \times$ cut & & $0.199(0.173)$ & & $-0.801 * *(0.277)$ & & & $-0.451(0.291)$ \\
\hline $\mathrm{OP} \times$ mai & & $0.244(0.157)$ & & & $0.714^{* * *}(0.172)$ & & $0.682 * * *(0.191)$ \\
\hline $\mathrm{OP} \times$ inc & & $0.255(0.174)$ & & & & $0.047(0.439)$ & $0.393(0.447)$ \\
\hline OP & $0.239 *(0.131)$ & & $0.453 *(0.193)$ & & & & \\
\hline STO & $0.179(0.145)$ & $0.183(0.155)$ & $-0.958^{* * *}(0.167)$ & $-0.489^{* * *}(0.130)$ & $-0.886^{* * *}(0.121)$ & $-0.679^{* * *}(0.125)$ & $-0.811^{* * *}(0.166)$ \\
\hline WGDP & $0.006(0.015)$ & $0.005(0.016)$ & $0.004(0.009)$ & $0.016(0.009)$ & $0.009(0.008)$ & $0.008(0.009)$ & $0.013(0.009)$ \\
\hline FR & $0.069(0.054)$ & $0.068(0.055)$ & $-0.110 *(0.043)$ & $-0.129 * *(0.041)$ & $-0.095 *(0.041)$ & $-0.136 * *(0.043)$ & $-0.088 *(0.041)$ \\
\hline PRO & $-0.064 * *(0.020)$ & $-0.063 * *(0.021)$ & $-0.189 * * *(0.026)$ & $-0.138^{* * *}(0.025)$ & $-0.178^{* * *}(0.023)$ & $-0.165^{* * *}(0.024)$ & $-0.16^{* * *}(0.025)$ \\
\hline Observations & 80 & 80 & 124 & 124 & 124 & 124 & 124 \\
\hline adjusted- $R^{2}$ & 0.110 & 0.086 & 0.434 & 0.447 & 0.484 & 0.407 & 0.495 \\
\hline $\mathrm{F}$ & $2.396^{*}$ & $1.832 *$ & $14.499 * * *$ & $15.215^{* * *}$ & $17.501 * * *$ & $13.093 * * *$ & $14.395 * * *$ \\
\hline $\mathrm{ARCH}$ & 0.588 & 0.521 & 0.739 & 0.729 & 0.450 & 0.746 & 0.569 \\
\hline
\end{tabular}

Note: standard errors are shown in parentheses. ${ }^{*}{ }^{* *}$ and, ${ }^{* * *}$ indicate significance at $0.10,0.01$, and 0.001 , respectively.

In terms of the interaction item, OPEC's announcements impose their significant influence on oil return risks only when the production remains unchanged during post-crisis periods (this result refers to column 5 in Table 4). However, other periods were not significantly dependent on the OPEC oil supply. These results indicate that the unchanged decisions were often regarded as non-decisions for different reasons. Economic parameters, such as market fundamentals, economic conditions or geopolitical events could result in OPEC changing its quota. Additionally, it is generally difficult for OPEC members to reach an announcement, and market investors heavily relate to OPEC members' degree of execution [59]. Thus, it could not be concluded that the market power of OPEC to promote the market stability by changing its production level has diminished. On the contrary, its role shows a heterogeneous conditions after global financial crisis [60]. As mentioned above, we can confirm that Hypotheses 2 and 3 are valid.

\section{Conclusions and Policy Implications}

The market reactions to OPEC's announcements can reflect the market power of OPEC and the expectations of market participants in the global crude oil market. Specifically, the empirical results with the event study methodology and with a framework of a linear model all point to the asymmetric market reactions to different OPEC announcements, as well as heterogeneous reaction during pre- and post-crisis periods. In this paper, we first explored the oil price reactions to OPEC's announcements and the heterogeneity to depict the directional role of OPEC based on the event study methodology. Furthermore, this paper analyzed the oil risk reactions in a framework of a linear model. Specific conclusions are as follows.

The oil price reactions to different OPEC announcements had stronger differences in crude oil markets, as well as during distinct periods. In general, the reactions to the announcements of a production increase showed an invert " $U$ " shape, whereas there was a linear reaction to cut decisions. In addition, when an unchanged decision was formulated, the oil prices had no obvious change over the sample period. According to the diverse mechanisms during pre- and post-crisis periods, this paper found an increase in oil production will drive prices up during pre-crisis periods, whereas it will drive oil prices to drop and then rise again dramatically during post-crisis periods. When a cut decision was announced, the reaction seemed to be more sensitive to oil price during pre-crisis periods than it was in the post-crisis periods. Additionally, the oil price reactions were moderate when the production quotas remain unchanged. 
The oil risk reactions to OPEC production decisions behaved quite heterogeneously in the three kinds of decisions. Actually, it is interesting to conclude that the oil risk reactions to OPEC's announcements were heavily related to the interaction item between OPEC decisions and its production over the full sample periods. Specifically, the interaction item between OPEC maintain decisions and its production had the highest positive influence on oil risks because of the market uncertainty. The reactions of oil risks to the production increase decisions were larger than the cut decisions. The picture changed a little during pre- and post-crisis periods. There were twofold heterogeneous reactions of oil return risks to OPEC's announcements: the single and interaction items. From the perspective of the single item, there were significant negative risk reactions to the OPEC increase decision, while the "cut decision" played a positive role on oil risks during post-crisis periods. In terms of the interaction item, OPEC's announcements imposed their significant influence on oil return risks only when the production remained unchanged during post-crisis periods. However, there were no significant reactions to other OPEC announcements.

These interesting results have implications for different stakeholders. On the one hand, the expectations of market participants play a dominant role on monitoring the instability caused by oil prices and risks. Thus, policymakers need to guide a reasonable expectation to ease the oil price volatility and decrease the oil return risks. On the other hand, investors pay attention to the maximization of profits. Thus, investors had better focus on the market conditions and the policy information. Additionally, they should also be familiar with economic parameters and make reasonable investments. Last but not least, the heterogeneous role of OPEC cannot be ignored by market participants in crude oil markets. Therefore, they should focus on the OPEC meeting decisions.

This paper was not without limitations. For example, we neglected the heterogeneous reactions to OPEC announcements during different trends in oil price, such as decrease or increase. This allows investors to make short investments to maximize their profits. Thus, we could further study this reaction by dividing the sample periods into two sub-periods. Additionally, it is interesting to note that the price gap between Brent and WTI fluctuated before and after 2011. Thus, further analysis about the heterogeneous reaction by adding more benchmark oil prices could be regarded as a valuable area. Moreover, the role of investor sentiment in crude oil markets could be further explored with the development of internet finance.

Author Contributions: Conceptualization, Y.L., H.D. and P.F.; Data curation, Y.L. and H.D.; Formal analysis, Y.L., H.D. and P.F.; Funding acquisition, Y.L.; Investigation, Y.L. and H.D.; Methodology, H.D.; Resources, Y.L. and P.F.; Software, H.D.; Supervision, Y.L. and P.F.; Validation, P.F.; Visualization, Y.L., H.D. and P.F.; Writing-original draft, Y.L., H.D. and P.F.; Writing-review and editing, Y.L., H.D. and P.F.

Funding: This research was funded by the Hunan Natural Science Foundation, grant number 2019JJ50111.

Acknowledgments: The authors are grateful to reviewers for helpful comments. The authors would like to thank Guangzhou University for sponsoring this research.

Conflicts of Interest: The authors declare no conflict of interest.

\section{References}

1. Brown, S.P.; Huntington, H.G. OPEC and world oil security. Energy Policy 2017, 108, 512-523. [CrossRef]

2. Gkillas, K.; Gupta, R.; Wohar, M.E. Volatility jumps: The role of geopolitical risks. Financ. Res. Lett. 2018, 27, 247-258. [CrossRef]

3. Loutia, A.; Mellios, C.; Andriosopoulos, K. Do OPEC announcements influence oil prices? Energy Policy 2016, 90, 262-272. [CrossRef]

4. Liao, G.; Li, Z.; Du, Z.; Liu, Y. The Heterogeneous Interconnections between Supply or Demand Side and Oil Risks. Energies 2019, 12, 2226. [CrossRef]

5. Balcilar, M.; Ozdemir, Z.A. The nexus between the oil price and its volatility risk in a stochastic volatility in the mean model with time-varying parameters. Resour. Policy 2019, 61, 572-584. [CrossRef]

6. Chen, H.; Liao, H.; Tang, B.J.; Wei, Y.M. Impacts of OPEC's political risk on the international crude oil prices: An empirical analysis based on the SVAR models. Energy Econ. 2016, 57, 42-49. [CrossRef] 
7. Draper, D.W. The behavior of event-related returns on oil futures contracts. J. Futures Mark. 1984, 4, 125. [CrossRef]

8. Liu, L.X.; Shu, H.; Wei, K.J. The impacts of political uncertainty on asset prices: Evidence from the Bo scandal in China. J. Financ. Econ. 2017, 125, 286-310. [CrossRef]

9. Weisbrod, E. Stockholders' Unrealized Returns and the Market Reaction to Financial Disclosures. J. Financ. 2019, 74, 899-942. [CrossRef]

10. Kurov, A.; Stan, R. Monetary policy uncertainty and the market reaction to macroeconomic news. J. Bank. Financ. 2018, 86, 127-142. [CrossRef]

11. Benkraiem, R.; Lahiani, A.; Miloudi, A.; Shahbaz, M. New insights into the US stock market reactions to energy price shocks. J. Int. Financ. Mark. Inst. Money 2018, 56, 169-187. [CrossRef]

12. Val, F.D.F.; Klotzle, M.C.; Pinto, A.C.F.; Barbedo, C.H.D.S. Stock market reaction to monetary policy: An event study analysis of the Brazilian case. Emerg. Mark. Financ. Trade 2018, 54, 2577-2595. [CrossRef]

13. Ji, Q.; Guo, J.F. Oil price volatility and oil-related events: An Internet concern study perspective. Appl. Energy 2015, 137, 256-264. [CrossRef]

14. Wang, J.; Wang, J. Forecasting energy market indices with recurrent neural networks: Case study of crude oil price fluctuations. Energy 2016, 102, 365-374. [CrossRef]

15. Bloch, H.; Rafiq, S.; Salim, R. Economic growth with coal, oil and renewable energy consumption in China: Prospects for fuel substitution. Econ. Model. 2015, 44, 104-115. [CrossRef]

16. Cunado, J.; Jo, S.; de Gracia, F.P. Macroeconomic impacts of oil price shocks in Asian economies. Energy Policy 2015, 86, 867-879. [CrossRef]

17. Phan, D.H.B.; Sharma, S.S.; Narayan, P.K. Oil price and stock returns of consumers and producers of crude oil. J. Int. Financ. Mark. Inst. Money 2015, 34, 245-262. [CrossRef]

18. Dai, Y.H.; Xie, W.J.; Jiang, Z.Q.; Jiang, G.J.; Zhou, W.X. Correlation structure and principal components in the global crude oil market. Empir. Econ. 2016, 51, 1501-1519. [CrossRef]

19. Mertzanis, C. Complexity, big data and financial stability. Quant. Financ. Econ. 2018, 2, 637-660. [CrossRef]

20. Bildirici, M.E.; Badur, M.M. The effects of oil prices on confidence and stock return in China, India and Russia. Quant. Financ. Econ 2018, 2, 884-903. [CrossRef]

21. Fattouh, B.; Mahadeva, L. OPEC: What difference has it made? Annu. Rev. Resour. Econ 2013, 5, 427-443. [CrossRef]

22. Mănescu, C.B.; Nuño, G. Quantitative effects of the shale oil revolution. Energy Policy 2015, 86, 855-866. [CrossRef]

23. Klein, T. Trends and contagion in WTI and Brent crude oil spot and futures markets-The role of OPEC in the last decade. Energy Econ. 2018, 75, 636-646. [CrossRef]

24. Wirl, F.; Kujundzic, A. The impact of OPEC Conference outcomes on world oil prices 1984-2001. Energy J. 2004, 25, 45-62. [CrossRef]

25. Genc, T.S. OPEC and demand response to crude oil prices. Energy Econ. 2017, 66, 238-246. [CrossRef]

26. Schmidbauer, H.; Rösch, A. OPEC news announcements: Effects on oil price expectation and volatility. Energy Econ. 2012, 34, 1656-1663. [CrossRef]

27. Mensi, W.; Hammoudeh, S.; Yoon, S.M. How do OPEC news and structural breaks impact returns and volatility in crude oil markets? Further evidence from a long memory process. Energy Econ. 2014, 42, 343-354. [CrossRef]

28. Pierru, A.; Smith, J.L.; Zamrik, T. OPEC's Impact on Oil Price Volatility: The Role of Spare Capacity. Energy J. 2018, 39, 103-122. [CrossRef]

29. Lin, S.X.; Tamvakis, M. OPEC announcements and their effects on crude oil prices. Energy Policy 2010, 38, 1010-1016. [CrossRef]

30. Baumeister, C.; Kilian, L. Forty years of oil price fluctuations: Why the price of oil may still surprise us. J. Econ. Perspect. 2016, 30, 139-160. [CrossRef]

31. Hong, Y.; Liu, Y.; Wang, S. Granger causality in risk and detection of extreme risk spillover between financial markets. J. Econ. 2009, 150, 271-287. [CrossRef]

32. Wen, D.; Wang, G.J.; Ma, C.; Wang, Y. Risk spillovers between oil and stock markets: A VAR for VaR analysis. Energy Econ. 2019, 80, 524-535. [CrossRef]

33. Juvenal, L.; Petrella, I. Speculation in the oil market. J. Appl. Econ. 2015, 30, 621-649. [CrossRef] 
34. Zhang, Y.J.; Zhang, L. Interpreting the crude oil price movements: Evidence from the Markov regime switching model. Appl. Energy 2015, 143, 96-109. [CrossRef]

35. Gallo, A.; Mason, P.; Shapiro, S.; Fabritius, M. What is behind the increase in oil prices? Analyzing oil consumption and supply relationship with oil price. Energy 2010, 35, 4126-4141. [CrossRef]

36. Li, Z.; Dong, H.; Huang, Z.; Failler, P. Impact of Foreign Direct Investment on Environmental Performance. Sustainability 2019, 11, 3538. [CrossRef]

37. MacKinlay, A.C. Event studies in economics and finance. J. Econ. Lit. 1997, 35, 13-39.

38. Al Rousan, S.; Sbia, R.; Tas, B.K.O. A dynamic network analysis of the world oil market: Analysis of OPEC and non-OPEC members. Energy Econ. 2018, 75, 28-41. [CrossRef]

39. Ghassan, H.B.; AlHajhoj, H.R. Long run dynamic volatilities between OPEC and non-OPEC crude oil prices. Appl. Energy 2016, 169, 384-394. [CrossRef]

40. Kisswani, K.M. Does OPEC act as a cartel? Empirical investigation of coordination behavior. Energy Policy 2016, 97, 171-180. [CrossRef]

41. Tsai, C.L. How do US stock returns respond differently to oil price shocks pre-crisis, within the financial crisis, and post-crisis? Energy Econ. 2015, 50, 47-62. [CrossRef]

42. Bampinas, G.; Panagiotidis, T. On the relationship between oil and gold before and after financial crisis: Linear, nonlinear and time-varying causality testing. Stud. Nonlinear Dyn. Econ. 2015, 19, 657-668. [CrossRef]

43. Bouri, E. Return and volatility linkages between oil prices and the Lebanese stock market in crisis periods. Energy 2015, 89, 365-371. [CrossRef]

44. Chen, Z.M.; Wang, L.; Zhang, X.B.; Zheng, X. The co-movement and asymmetry between energy and grain prices: Evidence from the crude oil and corn markets. Energies 2019, 12, 1373. [CrossRef]

45. Dičpinigaitienè, V.; Novickyte, L. Application of systemic risk measurement methods: A systematic review and meta-analysis using a network approach. Quant. Financ. Econ. 2018, 2, 798-820. [CrossRef]

46. Ferraty, F.; Quintela-Del-Río, A. Conditional VAR and Expected Shortfall: A New Functional Approach. Econ. Rev. 2016, 35, 263-292. [CrossRef]

47. Jacobs, M., Jr.; Sensenbrenner, F.J. A comparison of methodologies in the stress testing of credit risk-alternative scenario and dependency constructs. Quant. Financ. Econ. 2018, 2, 294-324. [CrossRef]

48. Righi, M.B.; Borenstein, D. A simulation comparison of risk measures for portfolio optimization. Financ. Res. Lett. 2018, 24, 105-112. [CrossRef]

49. Li, Z.H.; Dong, H.; Huang, Z.H.; Failler, P. Asymmetric Effects on Risks of Virtual Financial Assets (VFAs) in different regimes: A Case of Bitcoin. Quant. Financ. Econ. 2018, 2, 860-883. [CrossRef]

50. Dong, H.; Liu, Y.; Chang, J.Q. The heterogeneous linkage of economic policy uncertainty and oil return risks. Green Financ. 2019, 1, 46-66. [CrossRef]

51. Gong, X.; Wen, F.; Xia, X.H.; Huang, J.; Pan, B. Investigating the risk-return trade-off for crude oil futures using high-frequency data. Appl. Energy 2017, 196, 152-161. [CrossRef]

52. Engle, R.F.; Manganelli, S. CAViaR: Conditional Autoregressive Value at Risk by Regression Quantiles. J. Bus. Econ. Stat. 2004, 22, 367-381. [CrossRef]

53. Behrouzifar, M.; Araghi, E.S.; Meibodi, A.E. OPEC behavior: The volume of oil reserves announced. Energy Policy 2019, 127, 500-522. [CrossRef]

54. Huang, Z.; Liao, G.; Li, Z. Loaning scale and government subsidy for promoting green innovation. Technol. Forecast. Soc. Chang. 2019, 144, 148-156. [CrossRef]

55. Gupta, R.; Yoon, S.M. OPEC news and predictability of oil futures returns and volatility: Evidence from a nonparametric causality-in-quantiles approach. N. Am. J. Econ. Financ. 2018, 45, 206-214. [CrossRef]

56. Li, Z.; Liao, G.; Wang, Z.; Huang, Z. Green loan and subsidy for promoting clean production innovation. J. Clean Prod. 2018, 187, 421-431. [CrossRef]

57. Behar, A.; Ritz, R.A. OPEC vs US shale: Analyzing the shift to a market-share strategy. Energy Econ. 2017, 63, 185-198. [CrossRef]

58. Golombek, R.; Irarrazabal, A.A.; Ma, L. OPEC's market power: An empirical dominant firm model for the oil market. Energy Econ. 2018, 70, 98-115. [CrossRef]

59. Ghoddusi, H.; Nili, M.; Rastad, M. On quota violations of OPEC members. Energy Econ. 2017, 68, 410-422. [CrossRef]

60. Liu, B.Y.; Ji, Q.; Fan, Y. Dynamic return-volatility dependence and risk measure of CoVaR in the oil market: A time-varying mixed copula model. Energy Econ. 2017, 68, 53-65. [CrossRef] 
(C) 2019 by the authors. Licensee MDPI, Basel, Switzerland. This article is an open access article distributed under the terms and conditions of the Creative Commons Attribution (CC BY) license (http://creativecommons.org/licenses/by/4.0/). 